\title{
Hybridization between damselfishes Dascyllus aruanus and $D$. reticulatus on the Great Barrier Reef
}

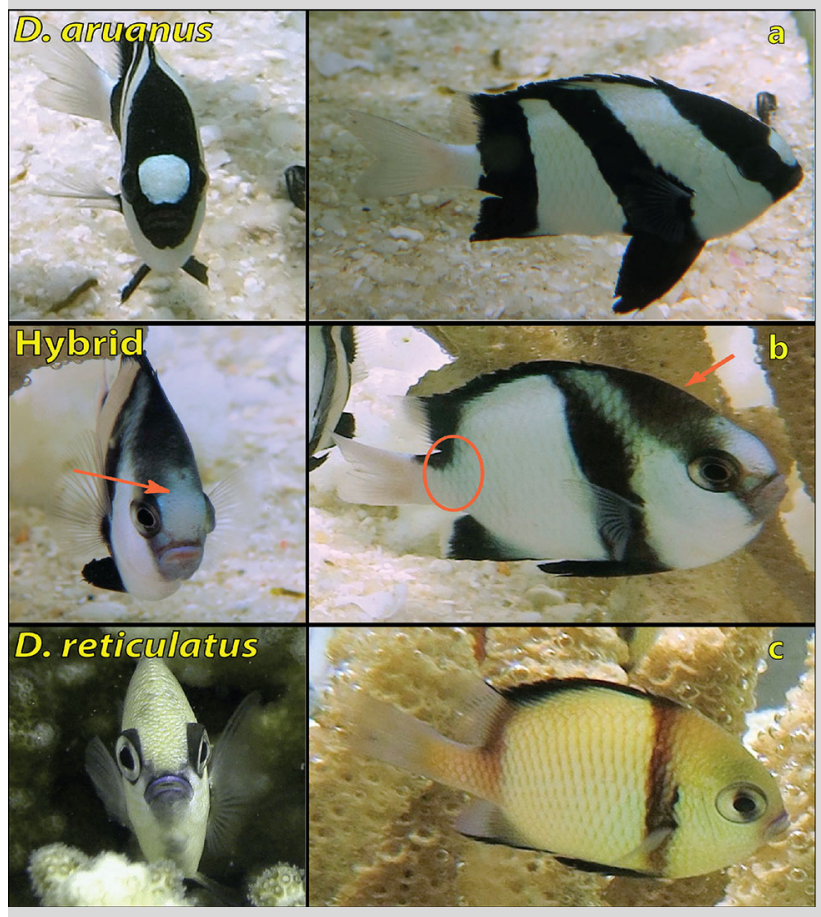

Fig. 1 Anterior and lateral view of Dascyllus aruanus (a), the hybrid (b) and $D$ reticulatus (c). Color features that separate this hybrid from both $D$. aruanus and $D$. reticulatus are marked in red

Hybridization among closely related species is relatively common in marine fishes that spawn mid-water. Although at least 81 species of tropical coral-reef fish have been reported to hybridize in nature (primarily Chaetodontidae, Pomacanthidae and Labridae), hybridization is thought to be exceedingly rare among benthic-nesting species that engage in pair spawning, such as the Pomacentridae (Montanari et al. 2016). The Pomacentridae include $>385$ species, most of which form breeding pairs and nest on the benthos. Yet only four Pomacentridae hybrids have been confirmed based on strong molecular evidence (e.g., Yaakub et al. 2006), and only from areas where one or both species are rare, such as degraded habitats and/or geographic zones of overlap. Here we present both morphological and genetic evidence for the first record of hybridization between Dascyllus aruanus and D. reticulatus (Fig. 1). These are small (4-9 cm total length, TL) benthic-nesting fishes that often cohabit small branching coral heads. They display distinct pairing during breeding, vigorously guarding their eggs until hatching.

The hybrid was found cohabiting a colony of Pocillopora damicornis with several D. aruanus and D. reticulatus at a depth of $6 \mathrm{~m}$ off Lizard Island $\left(14^{\circ} 40^{\prime} 08^{\prime \prime} \mathrm{S}\right.$, $\left.145^{\circ} 27^{\prime} 34^{\prime \prime} \mathrm{E}\right)$, Great Barrier Reef, Australia. The hybrid was adult size $(6 \mathrm{~cm}$ TL) and had coloration and meristic counts intermediate to both D. aruanus and D. reticulatus. Dascyllus aruanus is white with three broad black bars over the head, pectoral fins and anterior to the caudal fin (Fig. 1a). By comparison, D. reticulatus has a tan body and iris, with one thin black bar across the pectoral fins and along the dorsal margin (Fig. 1c). Both species have black pelvic fins, and pale caudal and pectoral fins. The hybrid had a white body with a light spot on the snout, two black bars over the head and pectoral fins, a black bar along the dorsal margin, but no bar across the anterior part of the caudal fin (Fig. 1b). It also had an intermediate number of soft dorsal fin rays and pectoral fin rays (14 and 19, respectively). However, the number of anal fin rays, tubed lateral line scales and gill rakers were identical only to D. reticulatus (14, 18 and 27, respectively). Analysis of a nuclear gene (TMO-4C4) revealed that the hybrid carried haplotypes identical to both parent species with the two lineages distributed evenly within the hybrid genotype. While Pomacentridae hybridization is rarely observed, this record emphasizes the potential for natural hybridization in areas of high abundance and well within geographic distribution limits.

\section{References}

Montanari SR, Hobbs JP, Pratchett MS, van Herwerden L (2016) The importance of ecological and behavioural data in studies of hybridisation among marine fishes. Reviews in Fish Biology and Fisheries 26:181-198

Yaakub SM, Bellwood DR, van Herwerden L, Walsh FM (2006) Hybridization in coral reef fishes: introgression and bi-directional gene exchange in Thalassoma (family Labridae). Mol Phylogenet Evol 40:84-100

J. L. Johansen ( $₫)$

Marine Science Institute, University of Texas at Austin, Port Aransas, TX 78373, USA

e-mail: jacob.johansen@my.jcu.edu.au

S. He · M. K. Pappas · M. L. Berumen

King Abdullah University of Science and Technology, Thuwal 23955, Saudi Arabia

G. Frank

James Cook University, Townsville, QLD 4811, Australia

A. S. Hoey

ARC Centre of Excellence for Coral Reef Studies, Townsville, QLD 4811, Australia

Received: 13 August 2016/ Accepted: 27 February 2017/Published online: 6 March 2017

Coral Reefs (2017) $36: 717$

(C) Springer-Verlag Berlin Heidelberg 2017 DOI $10.1007 / \mathrm{s} 00338-017-1563-\mathrm{z}$ 